\title{
Polyester Microplastic Fibers affect Soil Physical Properties and Erosion as a Function of Soil Type
}

Rosolino Ingraffia ${ }^{1,2,3^{*}}$, Gaetano Amato $^{1,4}$, Vincenzo Bagarello ${ }^{1}$, Francesco G. Carollo ${ }^{1}$, Dario Giambalvo $^{1,4}$, Massimo Iovino ${ }^{1}$, Anika Lehmann ${ }^{2,3}$, Matthias C. Rillig ${ }^{2,3}$, Alfonso S. Frenda ${ }^{1}$

$5 \quad{ }^{1}$ Department of Agricultural, Food and Forest Sciences, Università degli Studi di Palermo, Palermo, Italy;

${ }^{2}$ Plant Ecology, Institute of Biology, Freie Universität Berlin, Berlin, Germany;

${ }^{3}$ Berlin-Brandenburg Institute of Advanced Biodiversity Research, Berlin, Germany;

${ }^{4}$ Fondazione A. e S. Lima Mancuso, Piazza Marina 61, 90133, Palermo, Italy

Correspondence to: Rosolino Ingraffia (rosolino.ingraffia@unipa.it)

10 Abstract. Microplastic is recognized as a factor of global change affecting many environmental compartments. Agricultural soils are likely hotspots of microplastic contamination in terrestrial ecosystems and are of particular concern due to their role in food production. Microplastic has already been shown to be able to affect soil properties, but its effect on different soil types is poorly understood. Moreover, no information is available on how the presence of this pollutant can affect soil water erosion processes, which are extremely important issues in many environments. In the light of this, we performed two experiments (a microcosm and a mesocosm study) to investigate how the presence of polyester microplastic fibers affects soil physical and hydrological parameters and processes such as aggregate formation and soil erosion in three different agricultural soil types.

Our data show that the effects of polyester microplastic on soil physical parameters (including soil aggregation and erosion) are strongly dependent on soil type. We found that microplastic contamination can decrease the formation of new aggregates

20 but at the same time increase their stability in water, with effects on soil erosion stronger as the intrinsic erodibility of soil increases.

Overall, our results highlight the importance of broadly exploring soil properties such as texture, mineralogy, and organic carbon content to better understand how the various soil types respond to microplastic contamination.

\section{Introduction}

25 Although the production of plastic is relatively recent ( 1950), its versatility and low cost have made it one of the most used daily materials today and it is hard to think of a world without plastic. World production of plastics has exceeded 350 million tons per year. Only a modest fraction of it is recycled (6-26\%; Alimi et al., 2018) while the vast majority generates plastic waste. Improper disposal of plastic waste can lead to environmental contamination; and indeed, small plastic particles have been documented even in the most remote areas of the globe (Bergami et al., 2020; Napper et al., 2020). In the last decade, 
https://doi.org/10.5194/soil-2021-136

Preprint. Discussion started: 14 December 2021

(c) Author(s) 2021. CC BY 4.0 License.

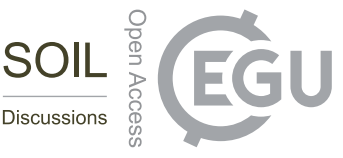

30 research on environmental impacts of plastic has received growing attention especially through the study of microplastic (defined as plastic particles smaller than $5 \mathrm{~mm}$; Hartmann et al., 2019).

Most studies on plastic pollution concern aquatic environments, although most plastics are likely present in the terrestrial environment (estimated in quantities 4 to 23 times greater than those in the ocean; Horton et al., 2017). Given their role in food production, agricultural ecosystems are of particular concern. Microplastics (MPs) can reach agricultural soils through different routes: (i) incorporation of compost, sewage, sludge, and other organic compounds often contaminated with MPs (Zubris and Richards, 2005; Weithmann et al. 2018); (ii) fragmentation of plastic films used for mulching (Qi et al. 2020) or (iii) atmospheric fallout (Dris et al. 2018). Therefore, it seems clear that agricultural land contains MPs and, considering that the degradation of plastic in the soil is generally very slow, the current hypothesis is that the MP content in agricultural land will slowly increase over time.

40 Once the MP particles reach the soil surface, they can be easily incorporated into the soil profile through terrestrial fauna: (earthworms: Rillig et al. 2017a; Collembola: Maaß et al. 2017), biopores, or mechanical operations, e.g., ploughing, or soil cracking (Rillig et al. 2017b). Therefore, MPs that reach the soil surface can be easily incorporated into soil and thus interact with soil bio-physical processes. Indeed, several studies have shown that the presence of MP can affect soil physical characteristics (bulk density, porosity, aggregate stability, water retention capacity, etc.) with effects widely differentiated in relation to the soil characteristics and MP type, shape and size (de Souza Machado et al., 2018; Zhang and Liu, 2018; Boots et al., 2019; Zhang et al., 2019; Lozano et al., 2021). As these soil characteristics are more or less strictly related to the susceptibility of soil erosion (Bradford et al., 1987; Lowery et al., 1995; Mamedov \& Levy, 2019), it is reasonable to expect that microplastics in the soil can influence water erosion processes, which are extremely important issues in many environments (Bagarello et al., 2018).

50 However, to the best of our knowledge, no research has been conducted to evaluate if and to what extent MP contamination of soil affects water erosion processes.

In light of the above, plastic likely represents a risk for the functionality and resilience of ecosystems. Moreover, due to erosion processes, microplastic particles embedded in the upper soil layer can be transported, eventually reaching water bodies such as rivers, lakes or the sea (Rehm et al., 2021). To better manage this situation, it is necessary to understand the

55 sources, movements, fate, and impacts of plastic when it reaches the different environmental compartments.

The main objective of this research is to expand the knowledge on the effects of MP contamination on the physical processes of three different soil types and evaluate the impact of MPs on the extent of water erosion processes. The underlying hypotheses are: 1) the impact of microplastic contamination on physical soil properties and hydrological processes differs with soil type, with more marked effects in the more "fragile" ones; 2) microplastic contamination, negatively affecting the

60 structural state of the soil, increases the extent of soil erosion. Collecting this information is essential for identifying solutions that can reduce the impact of microplastics on ecosystems and, at the same time, concentrate efforts in terms of resources and interventions in the most vulnerable areas. 
https://doi.org/10.5194/soil-2021-136

Preprint. Discussion started: 14 December 2021

(c) Author(s) 2021. CC BY 4.0 License.

(c) (i)

\section{Material and Methods}

\subsection{Soils and treatment with microplastics}

65 Three widely different soils were sampled at the end of October 2019 from the upper $30 \mathrm{~cm}$ of agricultural fields, classified according to the soil taxonomy and located as follows:

i) Typic Haploxerert (Vertisol; $37.556140^{\circ} \mathrm{N}, 13.515400^{\circ} \mathrm{E}, 360 \mathrm{~m}$ amsl). This soil type is widespread in Mediterranean environments with a flat or slightly sloping morphology. The sampled soil has a clay texture (Table 1), a good and stable structure, a sub-alkaline reaction, a fair or high presence of organic matter and other elements of fertility. Large and deep

70 cracks along the profile characterize this soil during the dry season. It has a medium-high production potential.

ii) Typic Xerorthent (Entisol; $37.561368^{\circ} \mathrm{N}, 13.512904^{\circ} \mathrm{E}, 414 \mathrm{~m}$ amsl). It is a light brown type of soil with a sub-alkaline reaction, widespread in the Mediterranean environment with steep and uneven morphologies, frequently affected by erosion phenomena; it generally has a limited thickness with an abundant skeleton presence. The structure is not very stable, the organic matter content is modest, and the production potential is medium-low.

75 iii) Typic Rhodoxeralfs (Alfisol; $37.643511^{\circ} \mathrm{N}, 12.628327^{\circ} \mathrm{E}, 38 \mathrm{~m} \mathrm{amsl}$ ). It is a typical soil widespread on the carbonate platforms of many Mediterranean environments; it can also be found in mountain contexts that are carbonated. The colour tends to be red due to the considerable presence of iron oxides linked to the leached clays. This soil is characterized by strong pedological aridity, due to its calcareous nature, and low amounts of organic matter and elements of fertility content.

After sampling, the soil was air dried, sieved at $600 \mu \mathrm{m}$ and stored at $4{ }^{\circ} \mathrm{C}$ until the beginning of the experiments in

80 December 2019. This was to minimize changes in the natural microbial community. Each soil was characterized by measuring particle size distribution (Gee et al., 1986), total nitrogen (TN; Kjeldhal), total organic carbon (TOC; WalkleyBlack procedure according to Nelson and Sommers 1996), $\mathrm{pH}$, saturated electrical conductivity at $25{ }^{\circ} \mathrm{C}$ (EC), and cation exchange capacity (CEC) (Table 1).

Table 1. Physical and chemical properties of the soils used in the experiment.

\begin{tabular}{ccccccccc}
\hline Soil & $\begin{array}{c}\text { Clay } \\
\left(\mathbf{g ~ k g}^{-1}\right)\end{array}$ & $\begin{array}{c}\text { Silt } \\
\left(\mathbf{g ~ k g}^{-1}\right)\end{array}$ & $\begin{array}{c}\text { Sand } \\
\left(\mathbf{g ~ k g}^{-1}\right)\end{array}$ & $\begin{array}{c}\text { TN } \\
\left(\mathbf{g ~ k g}^{-1}\right)\end{array}$ & $\begin{array}{c}\text { TOC } \\
\left(\mathbf{g ~ k g}^{-1}\right)\end{array}$ & $\mathbf{p H}$ & $\begin{array}{c}\mathbf{E C} \\
\left(\mathbf{d S ~ m}^{-1}\right)\end{array}$ & $\begin{array}{c}\text { CEC } \\
\left(\mathbf{c m o l ~ k g}^{-1}\right)\end{array}$ \\
\hline Vertisol & 415 & 357 & 228 & 1.54 & 15.78 & 7.74 & 1.89 & 30.0 \\
Entisol & 209 & 461 & 330 & 1.20 & 9.25 & 7.84 & 1.88 & 18.4 \\
Alfisol & 152 & 431 & 417 & 0.77 & 11.20 & 7.58 & 2.01 & 13.8 \\
\hline
\end{tabular}

TN, Total Nitrogen; TOC, Total Organic Carbon; EC, Electrical Conductivity; CEC, Cation Exchange Capacity.

For microplastic contamination, a 100\% polyester white rope (Marlow, Marlowbraid classic rope) was manually cut to produce secondary microplastics fibers. These fibers were characterized by scanning at least 200 fibers on PVC trays 10 times (Epson Perfection Scan V800, 8-bit grayscale, 800 dpi) and then analyzing the scans with WinRhizo (WinRHIZO Pro v. 2007d, Regent Instrument Inc., Quebec, Canada). The mean and the standard deviation, SD, of fiber length were $2.87 \mathrm{~mm}$ 
https://doi.org/10.5194/soil-2021-136

Preprint. Discussion started: 14 December 2021

(c) Author(s) 2021. CC BY 4.0 License.

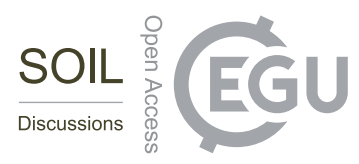

90

\section{5}

Lozano et al, 2020; Lehmann et al, 2020). The fibers were added into the blender (Waring® WSG30, Waring Commercial, Torrington, Connecticut) as a band sandwiched between two layers of soil. The mixture of soil and fibers was mixed five times for $5 \mathrm{~s}$ each. The same disturbance was also applied to the soil of the control treatment.

The three soil types, both treated and untreated, were used to fill 36 cylinders in total (height $=0.05 \mathrm{~m}$, diameter $=0.05 \mathrm{~m}$;

$10080 \mathrm{~g}$ of soil; Fig. 1a) to evaluate the impact of microplastic on soil properties (experiment 1 ) and 36 runoff plots of $0.30 \times$ $0.15 \times 0.10 \mathrm{~m}$ perforated at the bottom (Fig. 1b) for the rainfall simulation tests (experiment 2 ).
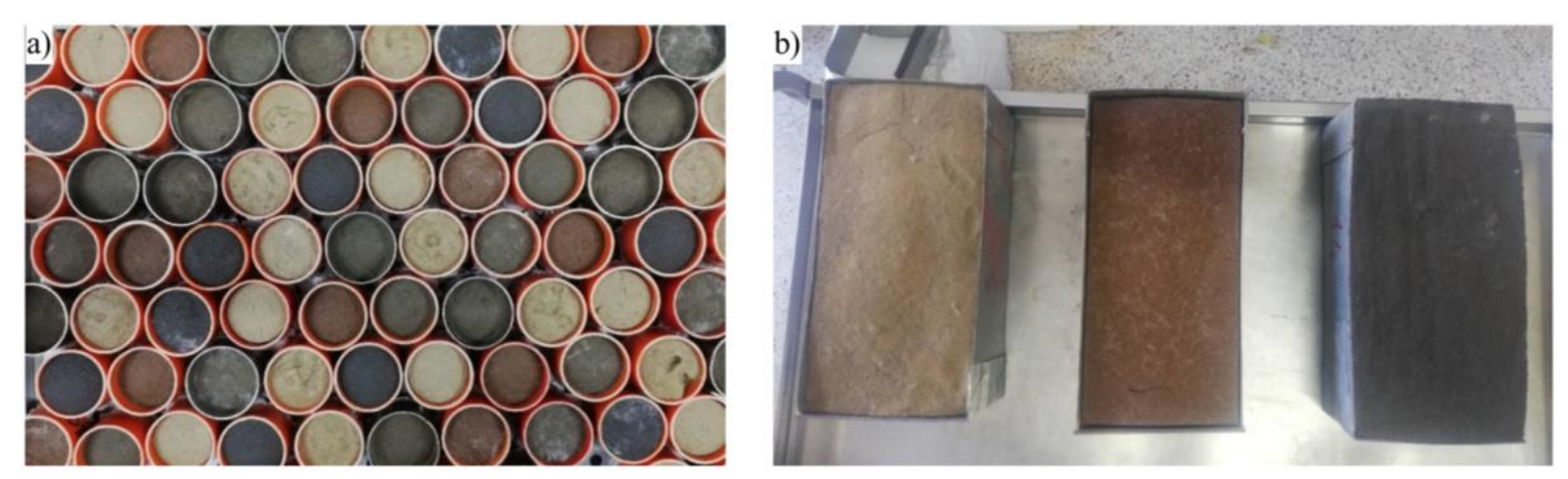

Figure 1. a) Cylinders and b) runoff plots used in the experiments.

For both treatments, that is the control (non-treated, Ctr) and the microplastics treated (MP) soil, the soil samples were

watered with distilled water to near field capacity by capillarity and then incubated in a growth chamber in the dark at $23 \pm 2$ ${ }^{\circ} \mathrm{C}$ and $60 \pm 5 \%$ relative humidity for nearly 6 months. During the incubation period, the soil samples were watered once a week with distilled water to field capacity by capillarity. The experimental units were re-randomized at each irrigation event. It was not possible to follow this protocol for 35 days (from April 7 to May 15, 2020) because of the national lockdown due to the COVID-19 pandemic. However, the status of the experimental units was checked after this period and no visual damage was observed.

\subsection{Experiment 1. Impact of microplastic on soil properties}

For each soil type, the Ctr treatment was set up in 8 replicates while the MP treatment consisted of 4 replicates (for a total of 36 cylindrical samples). 
The soil water retention curve was determined after incubation using the hanging water column apparatus (Dane and Hopmans, 2002a) for pressure head, $h$, values ranging from -0.03 to $-1 \mathrm{~m}$ and the pressure plate extractor (Dane and Hopmans, 2002b) for $\mathrm{h}$ values ranging from -3.3 to $-150 \mathrm{~m}$.

Briefly, the soil samples were placed on the porous plate of a glass funnel and saturated from the bottom by progressively raising the water level in a graduated burette (height was adjustable). Equilibration at $\mathrm{h}$ values of $-0.2,-0.1$, and $-0.05 \mathrm{~m}$ was obtained successively in steps of 24 hours each. Finally, the samples were fully saturated by submersion for 2 hours. From saturation, soil samples were desorbed by imposing a sequence of eight $\mathrm{h}$ values $(\mathrm{h}=-0.03,-0.05,-0.10,-0.20,-0.30,-0.50,-$ 0.70 , and $-1.0 \mathrm{~m}$ ). At each $\mathrm{h}$ level, the volume of drained water into the burette was recorded. The volumetric water content, $\theta\left(\mathrm{m}^{3} \mathrm{~m}^{-3}\right)$, at each equilibrium stage was calculated by adding the drained volumes to the value determined at $\mathrm{h}=-1 \mathrm{~m}$ after oven-drying. The dry soil bulk density, $B D\left(\mathrm{~g} \mathrm{~cm}^{-3}\right)$, was calculated by measuring the volume at the end of the experiment and using the oven-dried weight of the soil sample.

125 Then, the oven-dried soil samples were gently crushed and split into two sub-samples: one was used to determine the soil water content down to $-150 \mathrm{~m}$, while the other was used to determine the soil structure and the soil water-stable aggregates.

To determine the soil water content at lower pressure head values, the soil was packed to the same $B D$ value of the larger samples in rings with a diameter of $0.05 \mathrm{~m}$ and a height of $0.01 \mathrm{~m}$. These repacked soil samples were then used to determine the soil water content corresponding to $\mathrm{h}=-3.3,-10,-33$ and $-150 \mathrm{~m}$ using the pressure plate apparatus (Dane and Hopmans,

130 2002b).

The water retention model proposed by van Genuchten (1980) was then fitted to experimental data obtained for each soil sample and the water content values corresponding to saturation, $\theta_{s}$, and to the pressure heads $\mathrm{h}=-0.10,-1.0$, and $-150 \mathrm{~m}(\theta-$ $0.1, \theta-1.0, \theta-150)$ estimated from the model. The following "capacitive" indicators of soil physical quality were considered that are directly linked to the soil water retention properties (Reynolds et al., 2009; Iovino et al., 2016):

$$
\begin{array}{ll}
\text { Macroporosity } & P_{\text {mac }}=\theta_{s}-\theta_{-0.1} \\
\text { Air capacity } & A C=\theta_{s}-\theta_{-1.0} \\
\text { Plant available water capacity } & P A W C=\theta_{-1.0}-\theta_{-150}
\end{array}
$$

The Pmac indicator gives the volume of large (macro) pores (i.e. $>0.3 \mathrm{~mm}$ equivalent pore diameter), which indicates the soil's ability to quickly drain excess water and facilitate root proliferation (Reynolds et al., 2009). The AC index represents the ability of soil to store and provide essential soil air (Topp et al., 1997). The PAWC indicator is a measure of the ability of the soil to store and provide soil water that is available to crop roots.

To investigate soil structure and soil water-stable aggregates, we used a wet sieving apparatus (Retsch AS 200) with a set of stacked sieves mesh of $2 \mathrm{~mm}, 1 \mathrm{~mm}, 0.6 \mathrm{~mm}, 0.5 \mathrm{~mm}, 0.25 \mathrm{~mm}$, and $0.106 \mathrm{~mm}$. For the soil structure, we closed the water valve and we performed a dry sieving; the sieves were moved vertically at rate of 30 cycles per minute over a period of 3 
https://doi.org/10.5194/soil-2021-136

Preprint. Discussion started: 14 December 2021

(c) Author(s) 2021. CC BY 4.0 License.

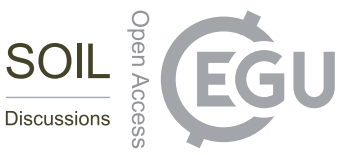

145 minutes, and after recording the weight of each sieved fraction, the whole sample was reconstructed and used to assess water-stable aggregates by using the same procedure with the opened water valve. As the soil at the beginning of the experiment was sieved at $600 \mu \mathrm{m}$, this method allowed us to also determine how our treatments affected the formation of new aggregates $(>600 \mu \mathrm{m})$ and the stability of these in water. All the analyses were conducted in a laboratory under controlled conditions of temperature (mean $\mathrm{T}=22^{\circ} \mathrm{C}$ ).

150 Data obtained from dry and wet sieving were used to calculate:

1) percentage of newly formed aggregates ( $>600 \mu \mathrm{m} ; N F A$ ) according to the following equation:

$$
\operatorname{NFA}(\%)=\frac{A_{\text {dry }>600}}{P_{\text {sample }}} \times 100
$$

where $A_{d r y}>600$ is the weight of the $>600 \mu \mathrm{m}$ fraction after air dried sieving process, $P_{\text {sample }}$ is the total weight of the sample.

2) percentage of water-stable newly formed aggregates ( $>600 \mu \mathrm{m}$; WSNFA) - calculated as following:

$$
\operatorname{WSNFA}(\%)=\frac{A_{w e t}>600}{A_{d r y>600}} \times 100
$$

where $A_{\text {wet }}>600$ is the weight of the $>600 \mu \mathrm{m}$ fraction after the wet sieving process.

3) water stability index $\left(S_{\text {index }}\right)$ - calculated as following:

$$
S_{\text {index }}=100-\frac{M W D_{w e t}}{M W D_{\text {dry }}} \times 100
$$

where $M W D_{\text {wet }}$ and $M W D_{d r y}$, are the mean weight diameter after wet and air dried sieving processes respectively, calculated 160 as follows,

$$
M W D=\sum_{i=1}^{7} \frac{A_{i}}{P_{\text {sample }}} \times d_{i}
$$

where $i$ is the fraction size $(>2 ; 1-2 ; 1-0.6 ; 0.6-0.5 ; 0.5-0.25 ; 0.25-0.106 ;<0.106 \mathrm{~mm}), A_{i}$ is the oven-dry weight of each fraction after sieving process (dry and wet); di is the mean diameter of each size fraction (i.e. the mean inter-sieve size; for the fraction $>2.0 \mathrm{~mm}$ (that was extremely low and always less than $1 \%$ ) it was considered $2.2 \mathrm{~mm}$ ).

\section{$165 \quad 2.3$ Experiment 2. Rainfall simulation}

Soil with (MP) and without (Ctr) microplastics was used to perform the experiments with the rainfall simulator. For a given treatment, air dried soil was used to fill the runoff plot after placing a cotton guard cloth at its bottom to avoid soil loss through the draining holes. The soil was gradually poured into the runoff plot and it was compacted manually by repeatedly dropping the runoff plot from a height of approximately 0.05-0.10 m until soil compaction ceased. Therefore, each soil 
https://doi.org/10.5194/soil-2021-136

Preprint. Discussion started: 14 December 2021

(c) Author(s) 2021. CC BY 4.0 License.

(c) (i)

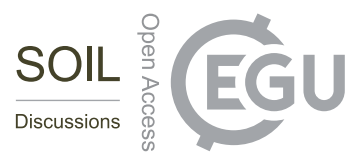

170 sample had an initial bulk volume of $0.30 \times 0.15 \times 0.10=4.50 \times 10^{-3} \mathrm{~m}^{3}$. For a given soil and a given treatment (MP and Ctr), six runoff plots were prepared (total sample size, $\mathrm{N}=3$ soils $\times 2$ treatments $\times 6$ runoff plots $=36$ ).

The rainfall simulator is a nozzle type rainfall simulator, very similar to those described by Ries et al. (2009) and Iserloh et al. (2012). The major parts of the rainfall simulator (Fig. 2a) are: a square metal frame $(120 \mathrm{~cm} \times 120 \mathrm{~cm})$ with a nozzle located at its centre and four telescopic steel legs in order to position the nozzle at a height ranging from 180 to $320 \mathrm{~cm}$

175 above the ground surface. A tank ensures the supply of water which is pressurized by a low pressure $12 \mathrm{~V}$ bilge pump (model Shurflo 2088 713-515) (Fig. 2b). The water supply to the tank assures a steady flow. The flow rate is regulated by the control valve located on a recirculation circuit and it is checked by a digital manometer (model PCE- DMM 10) characterized by an accuracy equal to $\pm 0.5 \%$. In order to check the pressure measure, a further analog manometer is installed.

180 Rainfall intensity and its uniformity over the wetted area were checked before performing the runoff and soil loss measurement experiment. Initially, a total of 55 plastic cups, each with an upper surface area of $35.3 \mathrm{~cm}^{2}$, were placed on a circular metal frame, with a diameter of $60 \mathrm{~cm}$, that was placed at a distance from the nozzle equal to the average distance between the nozzle and the runoff plots and centered exactly below the nozzle of the rainfall simulator (Fig. 2c). Simulated rainfall was collected for $30 \mathrm{~min}$ and a rainfall intensity value was then determined for each cup. Taking into account that

185 four plots were planned to simultaneously be subjected to a given rainfall event, rainfall uniformity among these plots was verified. In particular, the data obtained on the cups corresponding to each plot were averaged to obtain four mean rainfall intensity values, that is a value to be associated with each plot. Rainfall uniformity was assessed by calculating the following uniformity coefficient, CU (Christiansen, 1942):

$$
C U=100\left(1-\frac{\sum_{i}^{n}\left|R_{i}-R\right|}{n R}\right)
$$

190 being $\mathrm{n}=55$ the number of cups, $R_{i}=$ the rainfall intensity recorded by each cup and $R=$ the mean rainfall intensity. 
https://doi.org/10.5194/soil-2021-136

Preprint. Discussion started: 14 December 2021

(c) Author(s) 2021. CC BY 4.0 License.
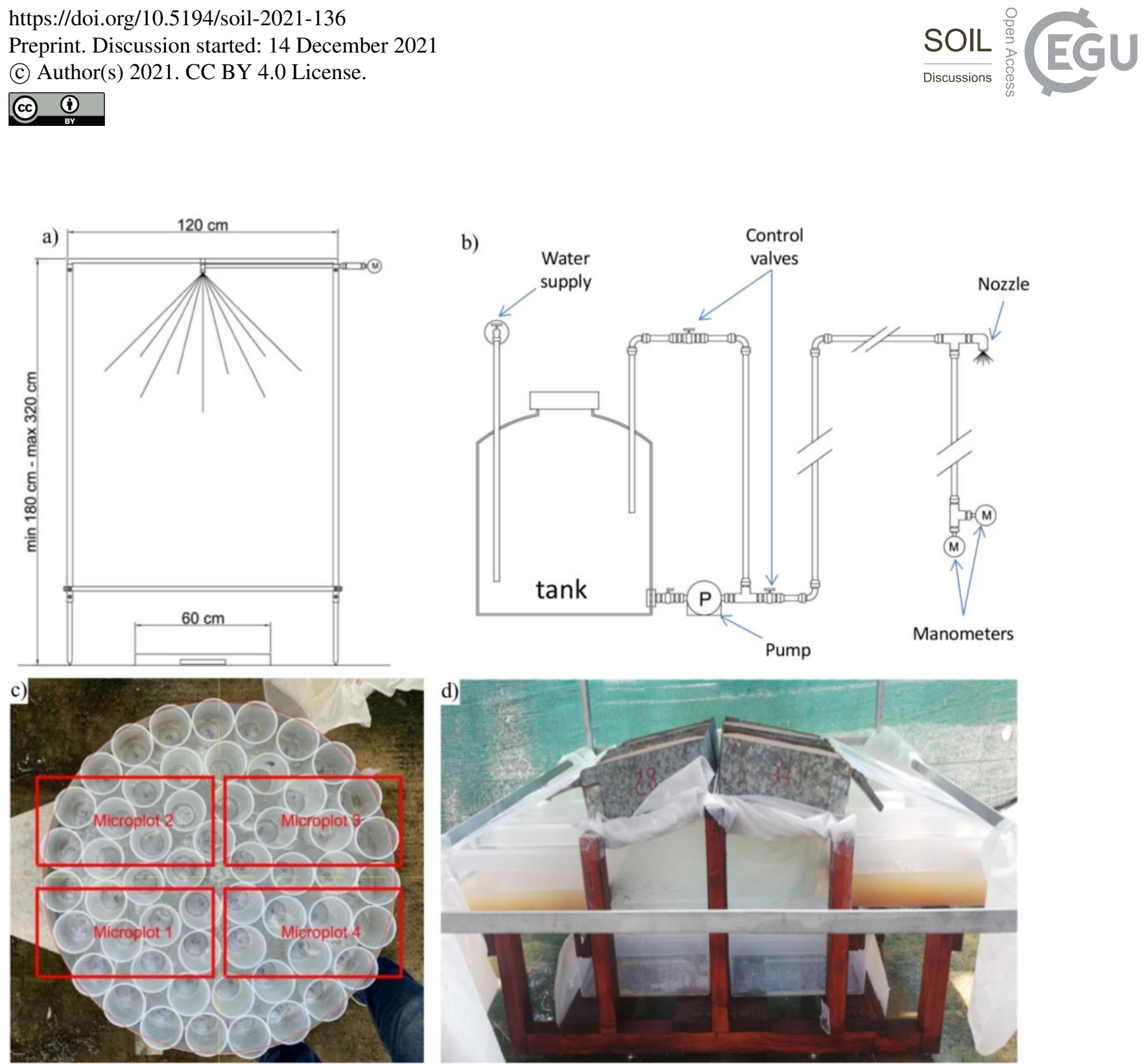

Figure 2. a) Scheme of the rainfall simulator and b) the hydraulic setup; c) arrangement of the plastic cups to evaluate rainfall intensity uniformity and overlap between the plastic cups and the micro-plots (in red); d) view of the experimental runoff plot during a rainfall simulation event.

195 Each individual rainfall simulation experiment was carried out by placing four runoff plots on a frame imposing a steepness of $15 \%$ to each plot (Fig. 2d). For each plot, surface runoff and the associated sediment load was conveyed through a gutter to a plastic container and the same was done with reference to deep percolation. Lids and plastic sheets were used in order to only expose soil surface to rainfall during the experiment. The runoff plot with the soil was weighed before and immediately after the rainfall event to obtain the change in the stored water in the soil volume. The whole experiment was carried out with a mean rainfall intensity of $33.4 \mathrm{~mm} \mathrm{~h}^{-1}(\mathrm{CV}=3.0 \%)$ and it had a duration of 2 hours. The rainfall simulation experiment was completed in nine days. At the beginning of each working day, rainfall intensity was measured by collecting water for ten minutes in a cylindrical bucket with a diameter of $30 \mathrm{~cm}$, and at a distance from the nozzle equal to the average distance between the runoff plots and the nozzle. 
https://doi.org/10.5194/soil-2021-136

Preprint. Discussion started: 14 December 2021

(c) Author(s) 2021. CC BY 4.0 License.

(c) (i)

At the end of the experiment, all containers were transported to the laboratory and dried at $105{ }^{\circ} \mathrm{C}$ to constant weight to determine the total surface runoff volume, the total drained water volume and the associated load of solids. For the drained water volume, this last quantity was always small and practically under the detectable quantity. Therefore, drained water was essentially clear in all cases. The data were then used to calculate, for each plot, total runoff per unit area, $V_{e}(\mathrm{~mm})$, total percolation per unit area, Pe $(\mathrm{mm})$, total soil loss per unit area, $A_{e}\left(\mathrm{~g} / \mathrm{m}^{2}\right)$, and sediment concentration in the surface runoff volume, $C_{e}\left(\mathrm{~g} / \mathrm{m}^{3}\right)$. A check of the reliability of the $V_{e}$ and $P_{e}$ data was made, taking into account that the sum of total runoff, total percolation and change in the stored water in the soil volume, denoted as $S_{e}(\mathrm{~mm})$, was expected to nearly coincide with the rainfall depth for the simulated event, $h_{e}$.

\subsection{Statistical analysis}

The data of both experiments were analyzed in R (R Core Team, 2020) using a generalized least square models in the "nlme" package (Pinheiro et al., 2018) with implemented varIdDent() function to account for heterogeneity of variance. Model 215 residuals were checked for heteroscedasticity and normal distribution.

All response variables within each soil type were compared between the two groups (MP minus Ctr) using the package "dabestr" (Ho et al, 2019) to calculate the effect sizes as unpaired mean differences and generate a bias-corrected and accelerated bootstrapped 95\% Confidence Intervals (CIs). We used this combined approach based on the expanding recognition of the limitation of using only "P-value statistic" approach and avoid dichotomous cutoffs (Ho et al, 2019; Wasserstein and Lazar, 2020).

\section{Results}

\subsection{Experiment 1}

The physical and hydrological effects of the treatment with microplastics differed with the soil type (Table S1). In particular, for the Vertisol, microplastic caused a decrease of bulk density (-9\%;), an increase in air capacity (+ 34\%; Fig. 3) whereas no effect was found on soil macroporosity and plant available water content (Fig. 4). In the Entisol, the contamination with MP did not cause any evident effects on the physical and hydrological characteristics. In the Alfisol, microplastic did not exert effects on the BD but induced pronounced decreases in both the AC (-26\%) and the Pmac (- 85\%) and an increase in the PAWC $(+19 \%)$. 
https://doi.org/10.5194/soil-2021-136

Preprint. Discussion started: 14 December 2021

(c) Author(s) 2021. CC BY 4.0 License.

SOLL EGE
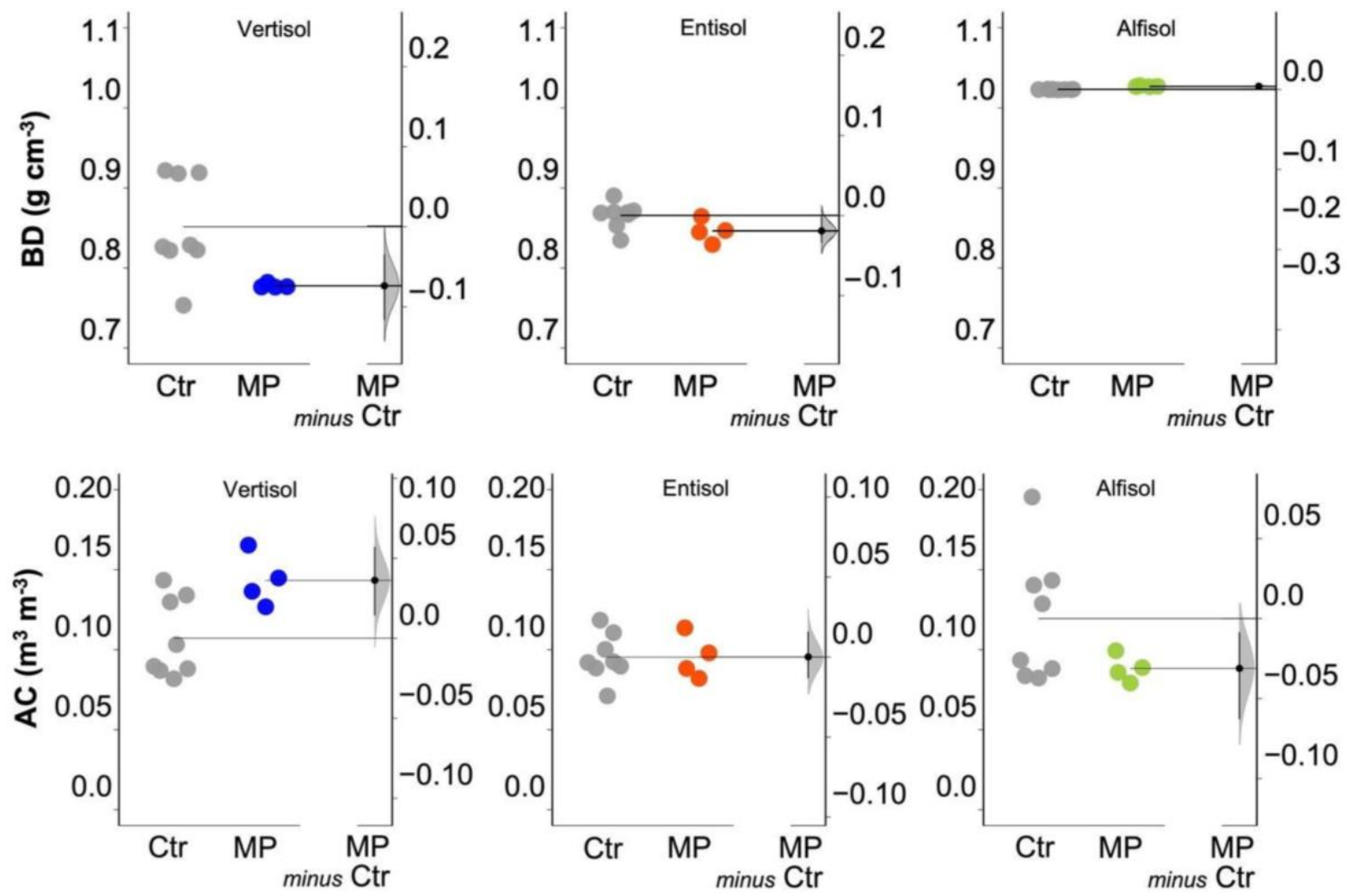

230 Figure 3. Soil bulk density (BD) and Air capacity (AC): raw data of Control (Ctr, grey dots) and Polyester microfibers added treatment (MP add, colored dots) are shown in the plot for each soil. The filled curve indicates the resampled distribution of mean differences $(\Delta)$, given the observed data. Horizontally aligned with the mean of the test group, $\Delta$ is indicated by the black circle. The $95 \%$ confidence interval of $\Delta$ is illustrated by the black vertical line. 
https://doi.org/10.5194/soil-2021-136

Preprint. Discussion started: 14 December 2021

(c) Author(s) 2021. CC BY 4.0 License.
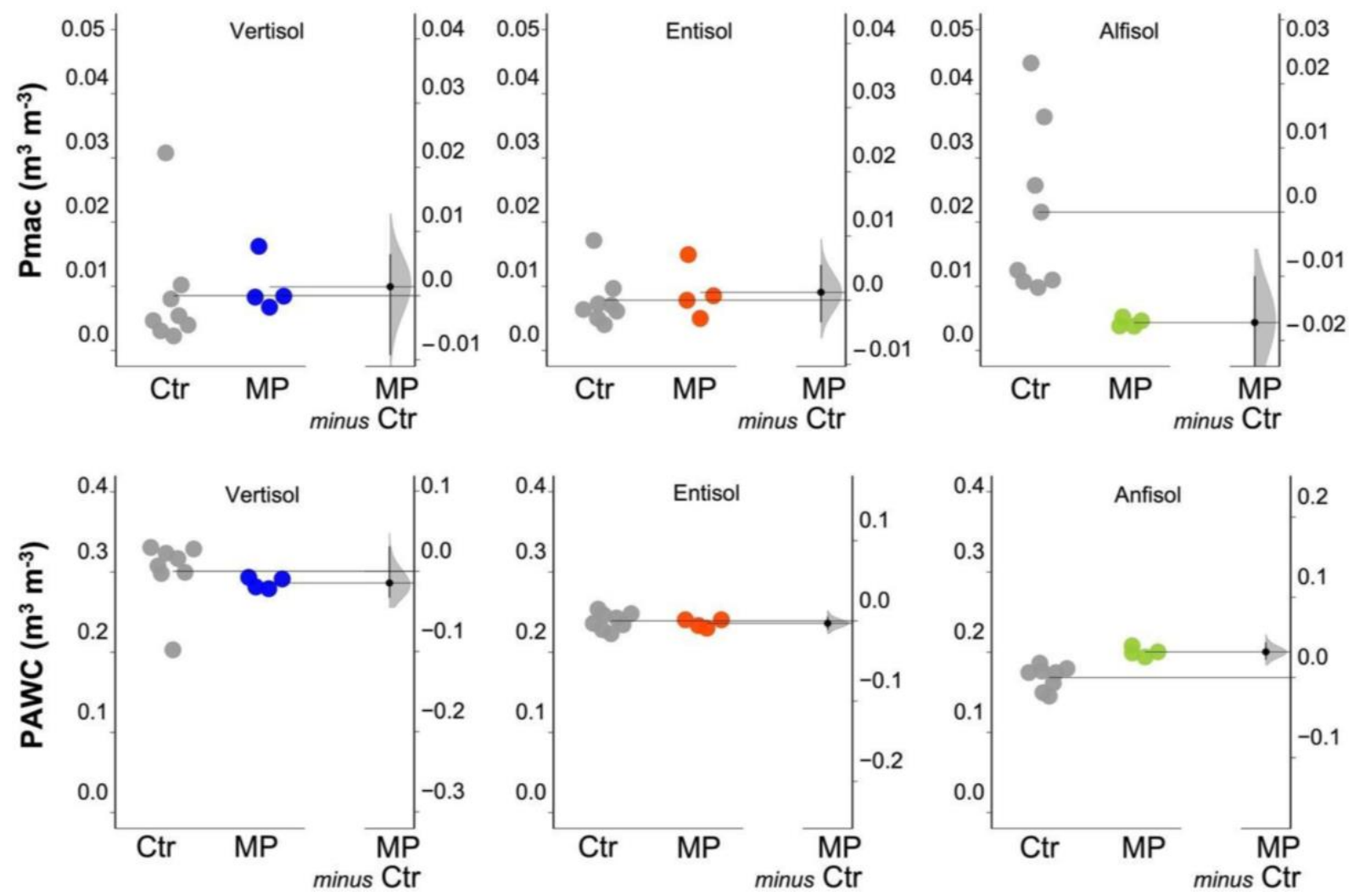

235 Figure 4. Soil macroporosity index (Pmac) and Plant available water content (PAWC): raw data of Control (Ctr, grey dots) and Polyester microfibers added treatment (MP add, colored dots) are shown in the plot for each soil. The filled curve indicates the resampled distribution of mean differences $(\Delta)$, given the observed data. Horizontally aligned with the mean of the test group, $\Delta$ is indicated by the black circle. The $95 \%$ confidence interval of $\Delta$ is illustrated by the black vertical line.

The data obtained from sieving (both dry and wet) show how the contamination with microplastics has negatively affected the percentage of newly formed aggregates $(>600 \mu \mathrm{m})(-32 \%$ in Vertisol; $-33 \%$ in Alfisol; $-47 \%$ in Entisol; ) but has, at the same time, increased their stability in water (+ 180\% in Vertisol; + 66\% in Alfisol; + 170\% in Entisol; Fig. 5).

The water stability index, calculated considering all the classes of aggregates, also increased due to the contamination with microplastics, although with different magnitude depending on soil type (Fig. 5). 
https://doi.org/10.5194/soil-2021-136

Preprint. Discussion started: 14 December 2021

(c) Author(s) 2021. CC BY 4.0 License.
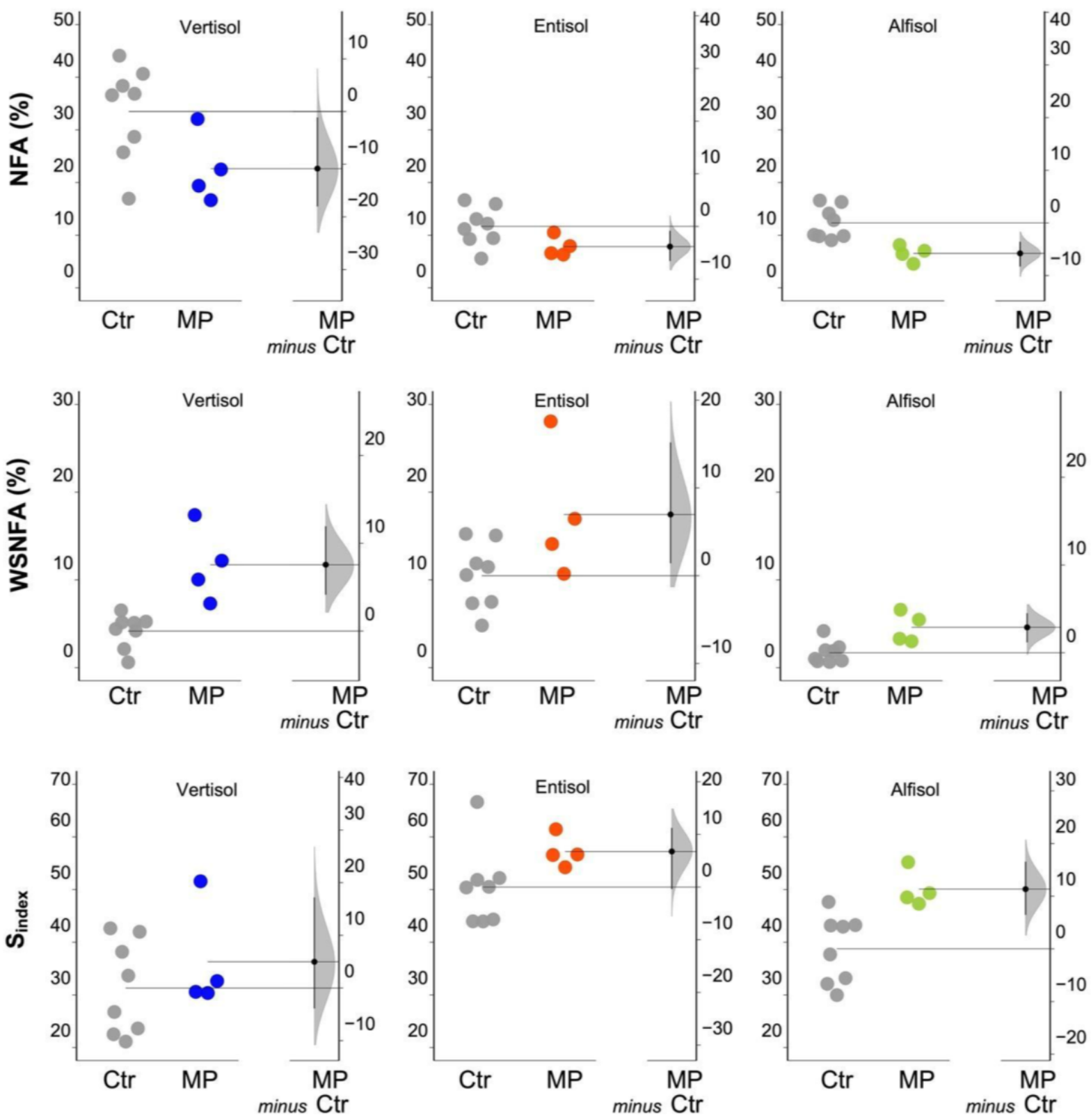

245 Figure 5. Newly formed aggregates (>0.6 mm; NFA), Water-stable newly formed aggregates (>0,6 mm; WSNFA), and Water stability index $\left(S_{\text {index }}\right)$ : raw data of Control (Ctr, grey dots) and Polyester microfibers added treatment (MP add, colored dots) are shown in the plot for each soil. The filled curve indicates the resampled distribution of mean differences $(\Delta)$, given the observed data. Horizontally aligned with the mean of the test group, $\Delta$ is indicated by the black circle. The $95 \%$ confidence interval of $\Delta$ is illustrated by the black vertical line. 
https://doi.org/10.5194/soil-2021-136

Preprint. Discussion started: 14 December 2021

(c) Author(s) 2021. CC BY 4.0 License.

(c) (i)

\subsection{Experiment 2}

\section{3.2.1 Preliminary check of the simulated rainfall}

Rainfall intensities, $R I$, measured by the 55 cups ranged from 31.3 to $37.4 \mathrm{~mm} \mathrm{~h}^{-1}$, with a mean of $33.8 \mathrm{~mm} \mathrm{~h}^{-1}$, a coefficient of variation, $C V=4.7 \%$ and a uniformity coefficient, $C U$, equal to $96.1 \%$. Considering only the cups corresponding to the area of the runoff plots, $R I=33.1 \mathrm{~mm} \mathrm{~h}^{-1}$ and $C U=97.1 \%$ was obtained. At the individual runoff plot scale, the mean rainfall intensity varied from 32.5 to $34.0 \mathrm{~mm} \mathrm{~h}^{-1}$, depending on the runoff plot, and the $C U$ values were in the range 96.8 98.2\%. As compared with the performances of other rainfall simulators (Iserloh et al. 2013), these results suggested that rainfall intensities were reasonably uniform among the four simultaneously tested runoff plots and also on each individual runoff plot.

Mean rainfall intensities were overall stable in the nine days of the rainfall simulator experiment (from 32.1 to $34.9 \mathrm{~mm} \mathrm{~h}^{-1}$ ). The whole experiment was carried out with a mean rainfall intensity of $33.4 \mathrm{~mm} \mathrm{~h}^{-1}(C V=3.0 \%)$ and it had a duration of 2 260 hours. Therefore, the mean rainfall depth, $h_{e}$, was $66.8 \mathrm{~mm}$.

On average, $h_{e}-\left(S_{e}+V_{e}+P_{e}\right)$ was equal to $5.3 \mathrm{~mm}$. However, neglecting the seven cases characterized by values of $h_{e}-\left(S_{e}+\right.$ $V_{e}+P_{e}$ ) greater than $20 \mathrm{~mm}$, for which some anomaly occurred in the experiment, the mean of the remaining 29 values of $h_{e}$ - $\left(S_{e}+V_{e}+P_{e}\right)$ is very close to zero $(0.14 \mathrm{~mm})$. Considering the consistency between $h_{e}$ and $\left(S_{e}+V_{e}+P_{e}\right)$, the seven suspect runs were excluded from the considered dataset to check soil treatment effect on $V_{e}, P_{e}$ and $A_{e}$.

\section{3.2.2 Runoff, percolation, soil erosion and sediment concentration}

Soil microplastic contamination did not induce changes in surface runoff (Fig. 6) in all soil types, although a slight decrease of $\mathrm{V}_{\mathrm{e}}$ was perceived for both the Entisol and the Alfisol. However, it affected percolation, which varied with the soil type. In particular, the analysis carried out separately by soil type allowed to highlight some different responses of the soils under evaluation; in the Alfisol, the contamination with microplastics increased percolation by 144\% (Fig. 6) as compared with the Ctr treatment. No effects were observed in the Vertisol and in the Entisol. 
https://doi.org/10.5194/soil-2021-136

Preprint. Discussion started: 14 December 2021

(c) Author(s) 2021. CC BY 4.0 License.
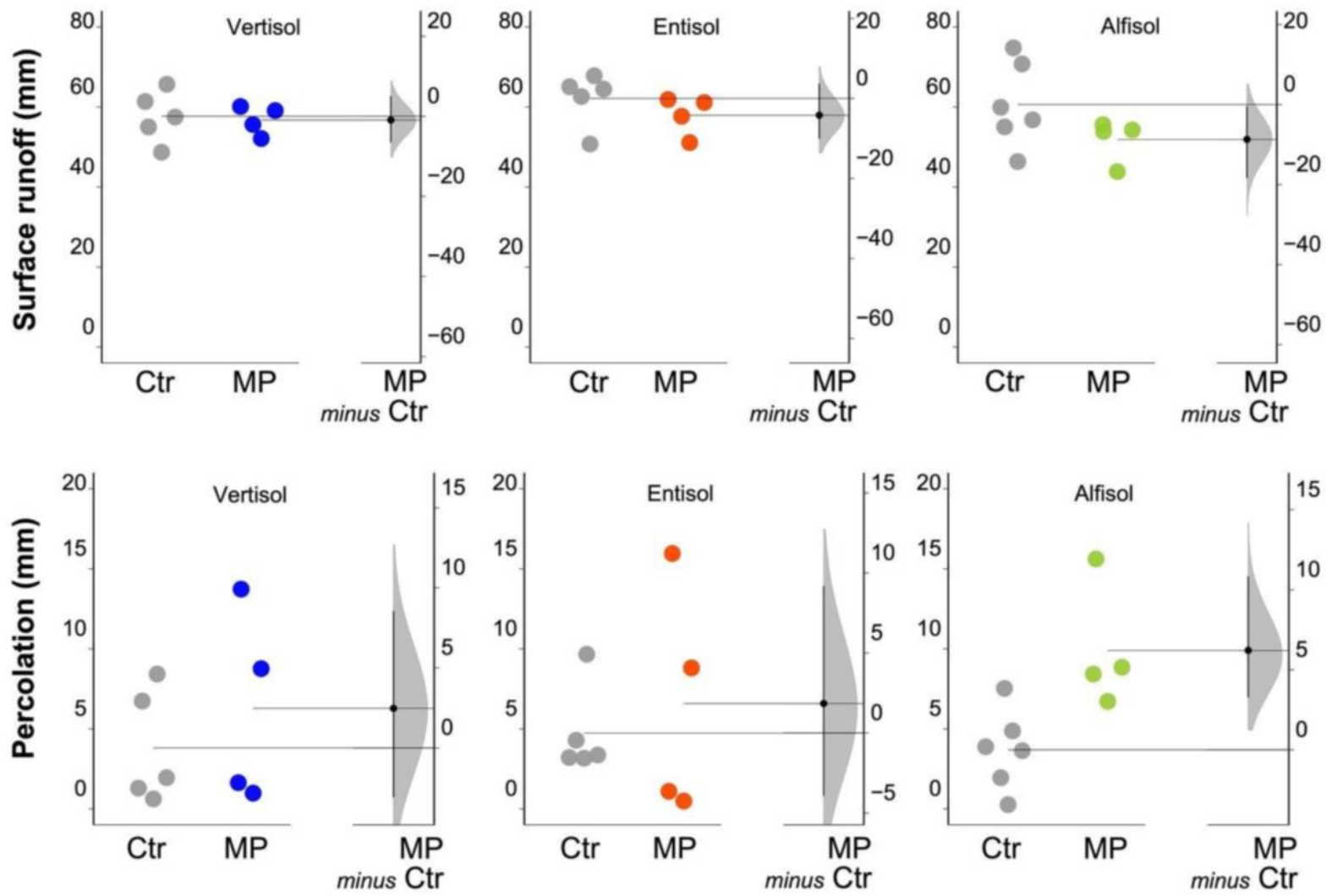

Figure 6. Surface runoff and Percolation: raw data of Control (Ctr, grey dots) and Polyester microfibers added treatment (MP add, colored dots) are shown in the plot for each soil. The filled curve indicates the resampled distribution of mean differences $(\Delta)$, given the observed data. Horizontally aligned with the mean of the test group, $\Delta$ is indicated by the black circle. The $95 \%$ confidence interval of $\Delta$ is illustrated by the black vertical line.

The extent of soil erosion varied widely among the soils under evaluation, resulting in a decidedly limited amount in Vertisol and in a particularly high one in Alfisol (Fig. 7). Contamination with microplastics did not cause variations in the quantities of eroded soil in the Vertisol, while it resulted in substantial reductions in both Entisol (-75\%) and Alfisol (-80\%). Similar results were observed for sediment concentration, as shown in Figure 7. 

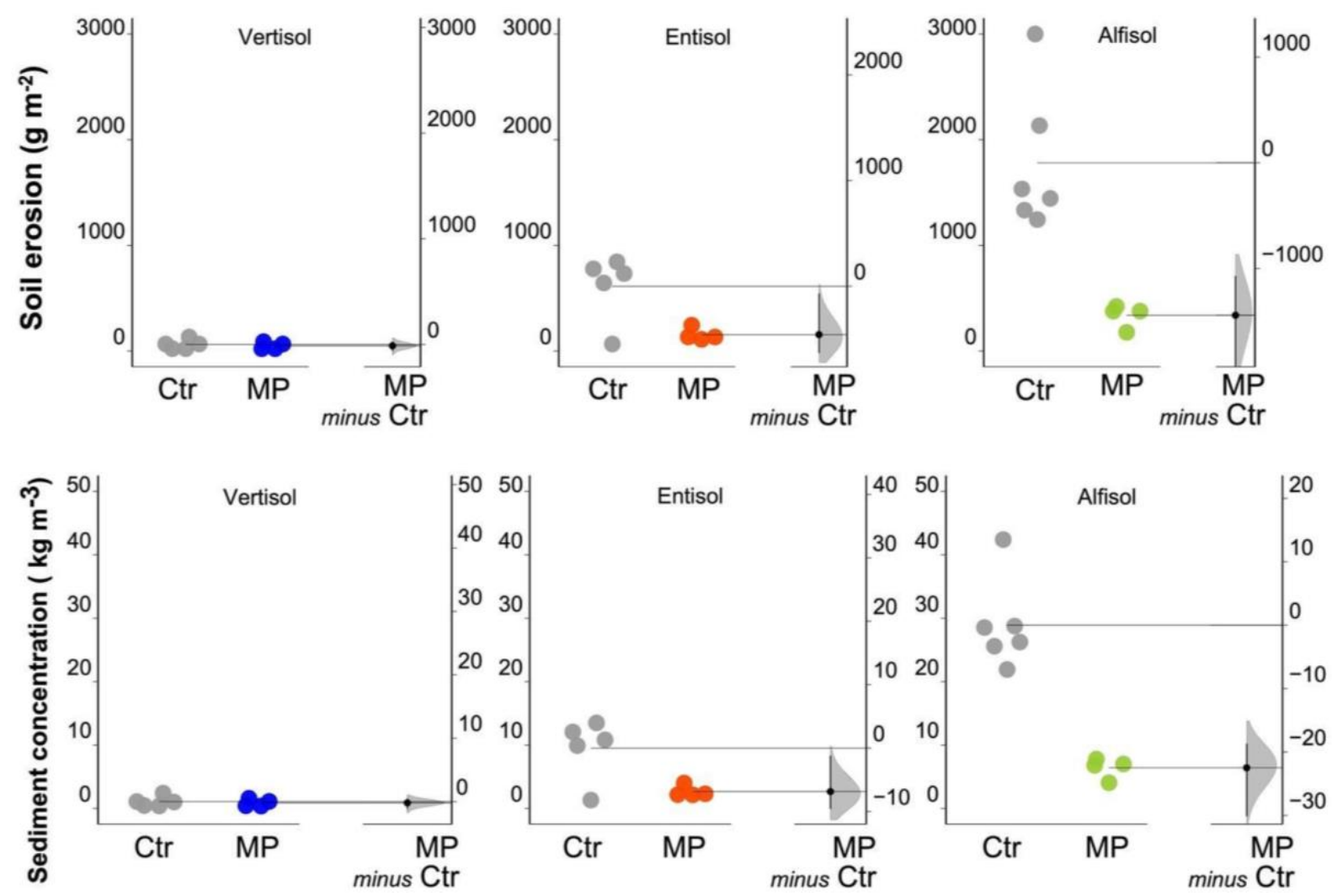

Figure 7. Soil erosion and Sediment concentration: raw data of Control (Ctr, grey dots) and Polyester microfibers added treatment (MP add, colored dots) are shown in the plot for each soil. The filled curve indicates the resampled distribution of mean differences $(\Delta)$, given the observed data. Horizontally aligned with the mean of the test group, $\Delta$ is indicated by the black circle. The $95 \%$ confidence interval of $\Delta$ is illustrated by the black vertical line.

\section{Discussion}

As hypothesized, the contamination with microplastics generally resulted in differentiated effects on soil structure and hydrological characteristics among the tested soils. In the Alfisol polyester microfibers have exerted the most marked effects, enhancing the water-holding capacity, reducing the formation of new aggregates and macroporosity and inducing an increase in water-stable aggregates. On the contrary, the Entisol was less affected by the presence of microplastics in terms of the physical and hydrological characteristics of the soil. Our results show that MP effects on soil structure and hydrological characteristics are related to the different characteristics of the soil used in the experiments, as already hypothesised by Zhang et al. (2019) and Xu et al. (2020). The results of this study, considering that the Entisol and the Alfisol studied do not differ substantially in particle size composition, highlight how the different response to MP contamination likely do not just depend on the soil texture. Other factors such as the different nature of their particles, and therefore the matrix from which they originated, can alter the interactions that are established between the particles themselves and polyester microfibers. This deserves further investigation to clarify the mechanisms causing the different responses observed. 
https://doi.org/10.5194/soil-2021-136

Preprint. Discussion started: 14 December 2021

(c) Author(s) 2021. CC BY 4.0 License.

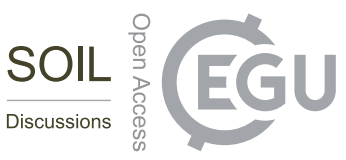

In the Vertisol, contamination with polyester microplastic fibers resulted in a decrease in soil bulk density and an increase in air capacity; on the contrary, in the other two studied soils, no variation in soil bulk density was observed. The data available in the literature about MP impact on soil bulk density are limited and not always concordant. For instance, de Souza

300 Machado et al. $(2018,2019)$ observed a decrease in bulk density in loamy sandy soils of increasing magnitude with increasing concentration of polyester microfibers while Zhang et al. (2019) in a study conducted on a clay loam soil (in field and greenhouse conditions) found no differences in soil bulk density.

Our results show how the presence of MP changes the cohesion between aggregate-forming particles reducing the formation of new aggregates. Similar results were observed by Boots et al (2019) and Lozano et al (2021). Zhang and Liu (2018) found that the abundance of aggregate-associated plastic fibers is greater in the micro-aggregates than in the macro-aggregates and this, according to the same authors, would suggest that the presence of fibers in the micro-aggregate limits their possibility to be combined into macro-aggregate. de Sosa Machado et al (2018) found that contamination of a loamy-sand soil with polyester fibers decreased the fraction of soil forming dry aggregates larger than $1 \mathrm{~mm}$ but at the same time increased the formation of large soil clumps and therefore potentially provided additional macro-structures, absent in the noncontaminated soil. In contrast, Zhang et al. (2019) found that polyester microplastic fibers improve soil aggregation helping to entangle soil particles more efficiently to form aggregates. Interestingly, in this experiment the effects of MP in soil aggregation varied among soil types highlighting how some soil characteristics (soil mineralogy, clay content, organic matter content, etc.) can influence its effects on the formation of soil aggregates. In particular, the negative effects induced by the addition of MP on the aggregation capacity of the soils were, to a certain extent, of increasing magnitude with increasing

315 TOC; it would therefore seem that the addition of MP interfered with the formation of macro-aggregates by altering the binding mechanism in the soil and, in particular, by reducing the aggregation capacity of organic matter. Similar results were also observed by Liang et al. (2021) who found that the effects of microplastic fibers on soil aggregation were organic matter dependent. However, in our study the contamination of soils with polyester fibers, in addition to determining a decrease in newly formed aggregates, induced a general increase in the water-stable aggregate profile; this effect appeared more marked in the clay soil (Vertisol) than in the two loam soils. Also, Zhang et al. (2019), in experiments conducted both in pots and in the field, observed a significant increase in the water stability of the macro-aggregates (> $2 \mathrm{~mm}$ ) and in the volume of the macro-pores (> $30 \mu \mathrm{m}$ ) after addition of polyester microfibers in a clay soil. In contrast, de Sosa Machado et al. (2018) found a significant decrease in water-stable aggregates with increasing polyester concentration in a sandy-loam soil. Evidently, soil mineralogy can be an important determinant for understanding the effects of MPs in the formation of macro-aggregates and their water stability. This suggests that the different soil particles may have a different affinity for the polyester fibers used here. The interactions that can occur between MP and soil fine particles are still poorly studied; acquiring this information is undoubtedly important in identifying which factors and mechanisms can influence the structure and stability of soils contaminated with MP.

Microplastic contamination did not affect surface runoff and drainage in the Vertisol and in the Entisol. It did cause a reduction of both parameters in the Alfisol, which has the coarsest texture among the three tested soils (Table 1). Moreover, 
https://doi.org/10.5194/soil-2021-136

Preprint. Discussion started: 14 December 2021

(c) Author(s) 2021. CC BY 4.0 License.

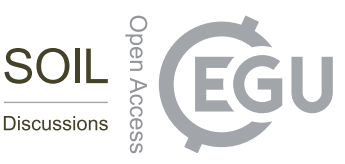

the three studied soils differed widely in susceptibility to erosion (Vertisol < Entisol < Alfisol); this result was partly expected, as many authors have highlighted how the increase in silt content and the reduction in organic matter contents lead to a greater susceptibility to soil erosion (Wischmeier and Smith, 1978; Chaney and Swift, 1984; Bonilla and Johnson, 2012). Adding polyester microplastic fibers had no effect on soil erosion in the less erodible soil (Vertisol), whereas it resulted in pronounced reductions in the most erodible soil (Alfisol). In other words, the tendency of microplastics to decrease soil erosion increased as the soil became intrinsically more erodible. The data therefore show that contamination with polyester microplastic fibers did not modify the soil hydrological behaviour (rainfall partition into surface runoff and percolation), but it strongly affected soil erosion phenomena. This influence was moderate or even negligible when the soil was inherently less erodible as a consequence of a relatively low silt content and a relatively high soil organic matter content.

340 Instead, it became appreciable in those cases in which erosion phenomena were noticeable since there was more silt and less organic matter. The anti-erosive effect of microplastics was more relevant as silt increased and organic matter decreased. This interpretation presupposes that the addition of microplastics essentially made the bonds among particles stronger and the $S_{\text {index }}$ values supported this conclusion. In other terms, adding microplastics made the soil structurally more stable, particularly when the soil was not inherently very stable. Therefore, this investigation suggested that the addition of microplastics did not alter appreciably its response in terms of surface runoff and percolation, but it modified the susceptibility of the soil particles to be detached by rainfall and surface runoff.

\section{Conclusion}

The results showed that the presence of polyester microfibers limits the neoformation of soil aggregates; likely, the microplastic fibers hinder the natural aggregation processes and, due to their shape and size and interposing between the fine soil particles, reduce the possibility of establishing bonds between them. Our data also highlighted how polyester microplastic fibers increase the water stability of aggregates; this result is somewhat unexpected, as it seems logical to assume that polyester microplastic fibers, by weakening the bonds and representing fracture lines within the aggregates, reduce their stability in water. Probably these negative effects were counterbalanced by a physical protective action offered by the fibers, which, by intercepting the raindrops, allowed the dissipation of their kinetic energy and limited the splash

355 effect that leads to the disintegration of the aggregates. This may explain why, in some cases, MP soil contamination has resulted in a very marked reduction in water erosion.

Finally, it emerged that the contamination of soils with MP exerts an impact on the structure, susceptibility to erosion and other hydrological characteristics of the soil as a function of soil type. This aspect is of great interest and underlines how a complete understanding of the potential impacts of MP on terrestrial ecosystems requires special attention to the processes

360 that occur in the soil and to the knowledge of the mechanisms underlying the different responses.

The applied experimental methodologies in this investigation provide much information on the effect of MP addition on several physical soil properties and hydrological processes. These methodologies should be applied in the future to different 
https://doi.org/10.5194/soil-2021-136

Preprint. Discussion started: 14 December 2021

(C) Author(s) 2021. CC BY 4.0 License.

son EG

MP concentrations (and types) to better understand the effects of MP on different soils and to help cover the potentially very large parameter space that, as suggested by Rillig and Lehman (2020), represents a major challenge of MP research in 365 terrestrial ecosystems. 
https://doi.org/10.5194/soil-2021-136

Preprint. Discussion started: 14 December 2021

(c) Author(s) 2021. CC BY 4.0 License.

(c) (1)

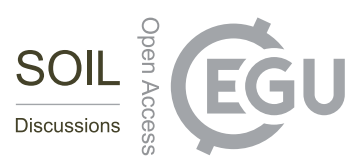

\section{Author contributions}

All authors (RI, GA, VB, FGC, DG, MI, AL, MCR, and ASF) conceptualized the study. GA, DG, and ASF acquired the funds to conduct the experiment. RI, FGC, DG, MI, and ASF carried out the experiments. RI, DG, and ASF analyzed the data. RI, DG, GA, ASF, MI, and VB wrote the first draft of the manuscript. AL and MCR collaborated on the ideas and contributed critically to the drafts. All authors gave the final approval for publication.

\section{Competing interests}

The authors declare that they have no conflict of interest.

\section{Acknowledgments}

The authors acknowledge funding from the University of Palermo (Palermo, Italy). 
https://doi.org/10.5194/soil-2021-136

Preprint. Discussion started: 14 December 2021

(c) Author(s) 2021. CC BY 4.0 License.

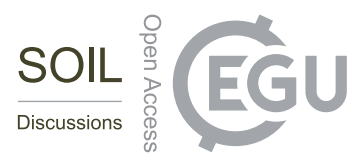

\section{References}

Alimi O.S., Farner Budarz J., Hernandez L.M., Tufenkji N. (2018). Microplastics and nanoplastics in aquatic environments: aggregation, deposition, and enhanced contaminant transport. Environmental Science \& Technology, 52(4): 1704-1724. https://doi.org/10.1007/s13369-020-04402-z

Bagarello V., Ferro V., Flanagan D.C. 2018. Predicting plot soil loss by empirical and process-oriented approaches. A review. Journal of Agricultural Engineering, vol. XLIX:710, 1-18, DOI: 10.4081/jae.2018.710.

Bergami, E., Rota, E., Caruso, T., Birarda, G., Vaccari, L., Corsi, I. (2020). Plastics everywhere: first evidence of polystyrene fragments inside the common Antarctic collembolan Cryptopygus antarcticus. Biology letters, 16(6), 20200093.

Bonilla C.A., Johnson O.I. 2012. Soil erodibility mapping and its correlation with soil properties in Central Chile. Geoderma, 189-190: 116-123. https://doi.org/10.1016/j.geoderma.2012.05.005

Boots B., Russell C.W., Green D.S. (2019). Effects of microplastics in soil ecosystems: above and below ground. Environmental Science \& Technology, 53(19): 11496-11506. https://doi.org/10.1021/acs.est.9b03304

Bradford, J. M., Ferris, J. E., \& Remley, P. A. (1987). Interrill Soil Erosion Processes: II. Relationship of Splash Detachment to Soil Properties. Soil Science Society of America Journal, 51(6), 1571-1575.

\section{0 https://doi.org/10.2136/sssaj1987.03615995005100060030x}

Christiansen J.E. 1942. Irrigation by Sprinkling. California Agricultural Experiment Station Bulletin 670.

Crossman J., Hurley R.R., Futter M., Nizzetto L. (2020). Transfer and transport of microplastics from biosolids to agricultural soils and the wider environment. Science of the Total Environment, 724, 138334.

Dane J.H., Hopmans J.W. 2002a 3.3.2.2 Hanging water column. p.680-683. In J.H.Dane and G.C.Topp (co-eds.), Methods of Soil Analysis, Part 4, Physical Methods, Number 5 in the Soil Science Society of America Book Series, Soil Science Society of America, Inc., Madison, WI, USA.

Dane J.H., Hopmans J.W. 2002b 3.3.2.4 Pressure plate extractor. p.688-690. In J.H.Dane and G.C.Topp (co-eds.), Methods of Soil Analysis, Part 4, Physical Methods, Number 5 in the Soil Science Society of America Book Series, Soil Science Society of America, Inc., Madison, WI, USA.

400 de Souza Machado, A. A., Lau, C. W., Kloas, W., Bergmann, J., Bachelier, J. B., Faltin, E., ... \& Rillig, M. C. (2019). Microplastics can change soil properties and affect plant performance. Environmental science \& technology, 53(10), 60446052. https://doi.org/10.1021/acs.est.9b01339

de Souza Machado, A.A., Lau, C.W., Till, J., Kloas, W., Lehmann, A., Becker, R., Rillig, M.C., 2018. Impacts of microplastics on the soil biophysical environment. Environ. Sci. Technol. 52 (17), 9656-9665. https://doi.org/10.1021/acs.est.8b02212.

Dris R., Gasperi J., Tassin B. (2018). Sources and fate of microplastics in urban areas: a focus on Paris megacity. In Freshwater Microplastics (pp. 69-83). Springer, Cham.

Gee G.W., Bauder J.W., Klute A. (1986). Methods of soil analysis, part 1, physical and mineralogical methods. Soil Science Society of America Book Series. American Society of Agronomy, Inc. and Soil Science Society of America, Inc. Madison, Wisconsin, 404-410.

Hartmann, N. B., Huffer, T., Thompson, R. C., Hassellöv, M., Verschoor, A., Daugaard, A. E., ... \& Wagner, M. (2019). Are we speaking the same language? Recommendations for a definition and categorization framework for plastic debris.

Ho J, Tumkaya T, Aryal S, Choi H, Claridge-Chang A. Moving beyond P values: data analysis with estimation graphics. Nat Methods. 2019 Jul;16(7):565-6. 
https://doi.org/10.5194/soil-2021-136

Preprint. Discussion started: 14 December 2021

(c) Author(s) 2021. CC BY 4.0 License.

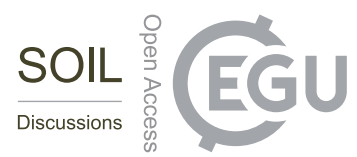

Horton A.A., Walton A., Spurgeon D.J., Lahive E., Svendsen C. (2017). Microplastics in freshwater and terrestrial environments: evaluating the current understanding to identify the knowledge gaps and future research priorities. Science of the Total Environment, 586: 127-141.

Iovino, M., Castellini, M., Bagarello, V., Giordano, G., 2016. Using Static and Dynamic Indicators to Evaluate Soil Physical Quality in a Sicilian Area. Land Degradation \& Development 27(2), 200-210.

Iserloh T., Fister W., Seeger M., Willger H., Ries J.B. (2012). A small portable rainfall simulator for reproducible experiments on soil erosion. Soil and Tillage Research, 124: 131-137. URL https://doi.org/10.1016/j.still.2012.05.016.

Iserloh T., Ries J.B., Arnáez J., Boix-Fayos C., Butzen V., Cerdà A., Echeverría M.T., Fernández-Gálvez J., Fister W., Geißler C., Gómez J.A., Gómez-Macpherson H., Kuhn N.J., Lázaro R., León F.J., Martínez-Mena M., Martínez-Murillo J.F., Marzen M., Mingorance M.D., Ortigosa L., Peters P., Regüés D., Ruiz-Sinoga J.D., Scholten T., Seeger M., SoléBenet A., Wengel R., Wirtz S. 2013. European small portable rainfall simulators: A comparison of rainfall characteristics. Catena, 110: 100-112, https://doi.org/10.1016/j.catena.2013.05.013.

Lehmann A., Leifheit E.F., Feng L., Bergmann J., Wulf A., Rillig M.C. (2020). Microplastic Fiber and Drought Effects on Plants and Soil Are Only Slightly Modified by Arbuscular Mycorrhizal Fungi. Soil Ecol. Lett. https://doi.org/10.1007/s42832-020-0060-4.

Liang, Y., Lehmann, A., Yang, G., Leifheit, E. F., \& Rillig, M. C. (2021). Effects of Microplastic Fibers on Soil Aggregation and Enzyme Activities Are Organic Matter Dependent. Frontiers in Environmental Science, 9, 97.

Liu M., Lu S., Song Y., Lei L., Hu J., Lv W., Zhou W., Cao C., Shi H., Yang X., He D. (2018). Microplastic and mesoplastic pollution in farmland soils in suburbs of Shanghai, China. Environmental Pollution, 242, 855-862.

Lozano Y.M., Lehnert T., Linck L.T., Lehmann A., Rillig, M.C. (2021). Microplastic Shape, Polymer Type, and Concentration Affect Soil Properties and Plant Biomass. Frontiers in Plant Science, 12, 169.

Lozano Y.M., Rillig M.C. (2020). Effects of Microplastic Fibers and Drought on Plant Communities. Environ. Sci. Technol., 54 (10), 6166-6173. https://doi.org/10.1021/acs.est.0c01051.

Lowery, B., Swan, J., Schumacher, T., \& Jones, A. (1995). Physical properties of selected soils by erosion class. Journal of Soil and Water Conservation, 50(3), 306-311.

440 Maß S., Daphi D., Lehmann A., Rillig M.C. (2017). Transport of microplastics by two collembolan species. Environmental Pollution, 225: 456-459.

Mamedov, A. I., \& Levy, G. J. (2019). Soil erosion-runoff relations on cultivated land: Insights from laboratory studies. European Journal of Soil Science, 70(3), 686-696. https://doi.org/10.1111/ejss.12759

Napper, I. E., Davies, B. F., Clifford, H., Elvin, S., Koldewey, H. J., Mayewski, P. A., ... \& Thompson, R. C. (2020).

445 Reaching new heights in plastic pollution - preliminary findings of microplastics on Mount Everest. One Earth, 3(5), 621 630.

Nelson D.W., Sommers L.E. (1996). Total carbon, organic carbon, and organic matter. Methods of soil analysis: Part 3 Chemical methods, 5, 961-1010.

Pinheiro, J., Bates, D., DebRoy, S., Sarkar, D., Team, R.C., 2018. nlme: Linear and nonlinear mixed effects models, R package version 3.1-137 ed.

Qi R., Jones D.L., Li Z., Liu Q., Yan C. (2020). Behavior of microplastics and plastic film residues in the soil environment: A critical review. Science of the Total Environment, 703: 134722.

Qi Y, Yang X, Pelaez AM, Lwanga EH, Beriot N, Gertsen H, Garbeva P., Geissen V. 2018. Macro-and micro-plastics in soil-plant system: effects of plastic mulch film residues on wheat (Triticum aestivum) growth. Science of the Total Environment, 645: 1048-1056. 
https://doi.org/10.5194/soil-2021-136

Preprint. Discussion started: 14 December 2021

(c) Author(s) 2021. CC BY 4.0 License.

(c) (i)

R Core Team 2020. R: A language and environment for statistical computing. R Foundation for Statistical Computing, Vienna, Austria. URL https://www.R-project.org/.

Rehm R., Zeyer T., Schmidt A., Fiener P. 2021. Soil erosion as transport pathway of microplastic from agriculture soils to aquatic ecosystems. Science of the Total Environment, 795, 148774.

460 Reynolds, W.D., Drury, C.F., Tan, C.S., Fox, C.A., Yang, X.M., 2009. Use of indicators and pore volume-function characteristics to quantify soil physical quality. Geoderma 152(3-4), 252-263.

Ries J.B., Seeger M., Iserloh T., Wistorf S., Fister W. (2009). Calibration of simulated rainfall characteristics for the study of soil erosion on agricultural land. Soil and Tillage Research, 106 (1): 109-116. URL https://doi.org/10.1016/j.still.2009.07.005.

Rillig M.C., Ingraffia R., de Souza Machado A.A. (2017b). Microplastic incorporation into soil in agroecosystems. Frontiers in Plant Science, 8: 1805.

Rillig, M. C., \& Lehmann, A. (2020). Microplastic in terrestrial ecosystems. Science, 368(6498), 1430-1431.

Rillig M.C., Ziersch L., Hempel S. (2017a). Microplastic transport in soil by earthworms. Scientific reports, 7(1), 1-6.

Topp, G.C.R., W.D.; Cook. F.J.; Kirby, J.M.; Carter, M.R., 1997. Physical attributes of soil quality. In: E.G.C. Gregorich,

470 M.R. (Ed.), Soil Quality for Crop Production and Ecosystem Health. Development in Soil Science. Elsevier, New York, NY, pp. 21-58.

van Genuchten, M.T., 1980. A Closed-form Equation for Predicting the Hydraulic Conductivity of Unsaturated Soils. Soil Science Society of America Journal, 44(5), 892-898.

Wasserstein R.L., Lazar N.A. ASA Statement on Statistical Significance and p-Values. In: Gruber CW, editor. The Theory

475 of Statistics in Psychology: Applications, Use, and Misunderstandings [Internet]. Cham: Springer International Publishing; 2020 [cited 2020 Oct 16]. p. 1-10. (Annals of Theoretical Psychology). Available from: https://doi.org/10.1007/978-3-03048043-1_1

Weithmann N., Möller J.N., Löder M.G., Piehl S., Laforsch C., Freitag R. (2018). Organic fertilizer as a vehicle for the entry of microplastic into the environment. Science Advances, 4(4): eaap8060.

480 Xu B., Liu F., Cryder Z., Huang D., Lu Z., He Y., Wang H. Lu Z., Brookes P.C. Tang C., Gan J., Xu J. (2020). Microplastics in the soil environment: occurrence, risks, interactions and fate-a review. Critical Reviews in Environmental Science and Technology, 50(21), 2175-2222.

Zhang G.S., Liu Y.F. (2018). The distribution of microplastics in soil aggregate fractions in southwestern China. Science of the Total Environment, 642: 12-20.

485 Zhang G.S., Zhang F.X., Li X.T. (2019). Effects of polyester microfibers on soil physical properties: Perception from a field and a pot experiment. Science of the total environment, 670: 1-7.

Zubris K.A.V., Richards B.K. (2005). Synthetic fibers as an indicator of land application of sludge. Environmental pollution, 138(2): 201-211. 